\title{
Emotional intelligence predicts peer-rated social competence above and beyond personality traits
}

\author{
Dorota Szczygiet $^{A, B, C, D, E, F}$, foanna Weber ${ }^{B, D, E, F}$ \\ SWPS University of Social Sciences and Humanities, Faculty in Sopot, Poland
}

BACKGROUND

This study investigated the relationship between trait emotional intelligence (EI) and social competences (SC), which determine effective functioning in three types of social situations: intimate situations, situations of social exposure and situations requiring self-assertion. Social competences were assessed using a peer nomination method. It was hypothesized that trait El predicts SC above and beyond personality traits.

\section{PARTICIPANTS AND PROCEDURE}

Data were collected from among 111 adolescents $(46.95 \%$ girls). The study was conducted among five classes from three public high schools. Participants first completed the Personality Inventory NEO-FFI and the Trait Emotional Intelligence Questionnaire-Short Form (TEIQue-SF). Subsequently, the descriptions of three different persons were presented to the participants. Each description concerned one of the SC: intimate competence, social exposure competence and assertive competence. Participants were asked to nominate three classmates who suited each description best.
RESULTS

A series of hierarchical regression analyses was performed. Personality traits and trait El were regressed on each competence. Analyses involved two-step hierarchical regressions, entering personality traits at step 1 and adding trait $\mathrm{EI}$ at step 2. The results demonstrated that personality traits explained a substantial portion of the variance in each SC. Beyond these variables, trait El was significant as a predictor of nominations for each SC, explaining an additional amount of the unique variance.

\section{CONCLUSIONS}

The results complement existing evidence that trait EI contributes to successful social functioning. The relationships between trait EI and SC remained statistically significant even after controlling for Big Five variance. The results demonstrate incremental validity of trait El over and above personality traits.

\section{KEY WORDS}

personality; emotional intelligence; adolescence; social competence

CORRESPONDIng AUTHOR - Dorota Szczygieł, Ph.D., SWPS University of Social Sciences and Humanities, Faculty in Sopot, 16/20 Polna Str., 81-745 Sopot, Poland, e-mail: dszczygiel@swps.edu.pl

AUthors' CONTRIBUtion - A: Study design - B: Data collection · C: Statistical analysis · D: Data interpretation .

E: Manuscript preparation · F: Literature search · G: Funds collection

TO CITE THIS ARTICLE - Szczygieł, D., \& Weber, J. (2017). Emotional intelligence predicts peer-rated social competence

above and beyond personality traits. Current Issues in Personality Psychology, 5(2), 91-101.

RECEIVED 18.08.2016 · REVIEWED 19.10.2016 · ACCEPTED 28.11.2016 • PUBLISHED 14.12.2016 


\section{BACKGROUND}

Growing appreciation of the importance of emotional intelligence (EI) has led to a significant increase in research in this area. Despite the conceptual differences in various approaches to EI, some constituents of EI are present in most theoretical frameworks. These include the ability to perceive one's own and other people's emotions, the ability to discriminate between different emotions and label them appropriately, and the ability to regulate emotions and use emotional information to guide thinking and behaviour (Mayer \& Salovey, 1997; Petrides \& Furnham, 2003; Salovey \& Mayer, 1990). An increasing number of studies demonstrate that EI is crucial for various aspects of effective adaptation, ranging from affective functioning to interpersonal relations (e.g., Chamorro-Premuzic, Bennett, \& Furnham, 2007; Jasielska \& Leopold, 2000; Mayer, Salovey, \& Caruso, 2004; Ogińska-Bulik, 2005; Sevdalis, Petrides, \& Harvey, 2007; Szczygieł \& Baka, 2016; Szczygieł \& Bazińska, 2013; Villanueva \& Sanchez, 2007).

The abilities included in the EI construct are thought to be important for social interactions because emotions are powerful regulators of interpersonal and group processes (Fischer \& Manstead, 2008). Emotions convey information about people's intentions and thoughts (Keltner \& Haidt, 2001), regulate the distance between individuals (Levenson, 1999), and enable people to establish and maintain long-term and intimate relationships that are durable and stable over time (Lopes, Salovey, \& Straus, 2003; Fischer \& Manstead, 2008). Positive emotions prompt individuals to engage with their social environment (Fredrickson, 2001). In contrast, negative emotions serve a social distancing function by helping individuals to differentiate from others and even to compete with these others for power and social status (Fischer $\&$ Manstead, 2008). Therefore, in order to deal with the challenges of social life, people need to possess the ability to reason about emotions and to use emotions effectively.

Salovey, Bedell, Detweiler, and Mayer (1999) claim that people who are in touch with their emotions are more likely to gain access to rich social support networks. Indeed, Ciarrochi, Deane, Wilson, and Rickwood (2002) demonstrated that individuals high in EI (as compared to individuals low in trait EI) receive more social support. There is also evidence that people high in EI declare more satisfaction from their relationships and perceive them as more supportive (Szczygieł, Jasielska, \& Wytykowska, 2015). Lopes and colleagues (2003) demonstrated that EI predicts popularity in social groups and influences both the quantity and quality of interpersonal relationships. Lopes et al. (2004) observed that the ability to manage emotions, one of the core features of EI, was positively associated with the perceived quality of interactions with both friends and individuals of the opposite sex. These results were corroborated by Lopes, Salovey, Côté, Beers, and Petty (2005), who demonstrated that emotion regulation abilities were positively related to both self-reports and peer nominations of interpersonal sensitivity and prosocial tendencies. Research also shows that high EI is associated with better leadership skills and a greater tendency to cooperative behaviour (McElravy \& Hastings, 2014; Matczak, 2007; Mavroveli, Petrides, Rieffe, $\&$ Bakker, 2007). The foregoing studies constitute important evidence that EI is related to social functioning. The aim of the current study is to examine the role of trait EI in predicting social competence.

\section{TRAIT EMOTIONAL INTELLIGENCE}

A number of conceptualizations of EI has been proposed. In order to organize inconsistencies in definitions of EI, Petrides and Furnham (e.g., Petrides \& Furnham, 2001) classified EI models into two categories: ability models (e.g., Mayer \& Salovey, 1997) and trait models (e.g., Petrides \& Furnham, 2003). Ability EI is defined as the ability to perceive and express emotion, assimilate emotion in thought, understand emotion, and regulate emotion in oneself and others (Mayer \& Salovey, 1997). Trait EI (alternatively known as trait emotional self-efficacy; see Petrides, 2011) is defined as a constellation of self-perceptions located at the lower levels of personality hierarchies (Petrides, Pita, \& Kokkinaki, 2007). Therefore, the former refers to individuals' ability to use emotions and emotional knowledge (i.e., what a person is capable of doing), whereas the latter refers to people's self-perceptions of their emotional abilities and is intended to capture what a person actually does (i.e., how much of these abilities manifest in practice) (Petrides \& Furnham, 2001).

The distinction between these two models is based solely on the method used to measure the construct, rather than on the constituents of EI that both models are supposed to cover (for discussion, see Petrides, 2011). Ability EI is measured by performance tests and, therefore, refers to maximum performance (Mayer, Salovey, Caruso, \& Sitarenios, 2003; Szczygieł, Buczny, \& Bazińska, 2013), whereas trait EI is assessed by self-report inventories referring to typical performance (Petrides, 2011). Accordingly, ability EI belongs to the domain of cognitive ability, while trait EI belongs to the realm of personality (Petrides, 2011), and this explains why the relationship between self-report methods and performance tests is relatively weak (e.g., Lumley, Gustavson, Partridge, \& Labouvie-Vief, 2005).

Understanding EI as a trait refers to the individual emotional dispositions, subjective perception of emotional experience and skills possessed by people in 
the areas relevant to EI (Petrides, 2011). Constituent elements of trait EI are: emotional perception, emotion expression, relationships, trait empathy, trait optimism, trait happiness, emotional management, assertiveness, social awareness, emotion regulation, impulsiveness (low), stress management, self-esteem, adaptability and self-motivation (Petrides, 2011). The Trait Emotional Intelligence Questionnaire (TEIQue; Petrides et al., 2007) is a self-report questionnaire that has been developed to cover the trait EI sampling domain (Petrides \& Furnham, 2001).

It should be noted that although ability and trait EI models are sometimes regarded as competitors, both approaches have advantages and should be considered as complementary rather than contradictory (for discussion, see Ciarrochi, Chan, \& Caputi, 2000; McCrae, 2000). The distinction between trait and ability EI is now regarded as a standard in the scientific literature, which helps to organize the increase of knowledge in the field (Austin \& Saklofske, 2010; Petrides, 2011).

\section{TRAIT EMOTIONAL INTELLIGENCE AND SOCIAL COMPETENCE}

Matczak $(2001,2007)$ defines social competence as the acquired ability which determines effective functioning in social situations. According to Matczak (2007), social competence consists of many different skills, which manifest themselves in three general types of social situations: (1) intimate situations, which require close interpersonal contacts and are associated with a disclosure of personal information by the partners of the interaction; (2) situations of social exposure, in which an individual is in the centre of social attention and can potentially be evaluated by other people, and (3) situations that require assertiveness, in which a person tries to achieve their goals by exerting social influence on other people (Matczak, 2001).

Consequently, Matczak (2001) distinguished three types of social competences: (1) intimate competences, which determine effective behaviour in close interpersonal relationships, (2) social exposure competences, which determine effective behaviour in conditions of social exposure, and (3) assertive competences, which determine effective behaviour in conditions requiring assertiveness. According to Matczak (2001), social competencies are learned during the social training process and formed on the basis of personality and intellectual features of which the crucial ones are social intelligence and EI (see also Martowska, 2012, 2014). Thus, EI is considered as a facilitator of the development of social competences (Matczak \& Knopp, 2013; Matczak \& Martowska, 2011).

The Social Competence Questionnaire (SCQ; Matczak, 2001) is a self-reported measure designed for the assessment of social competences proposed by Matczak (2001, 2007). Respondents are asked to assess their functioning in intimate situations (e.g., "Hugging a person who needs consolation"), in situations requiring social exposure (e.g., "Speaking in public"), and in situations requiring assertiveness (e.g., "Refusing to lend money to a friend"). Szczygieł and colleagues (2015) examined the relationship between trait EI and self-reported social competences assessed by the SCQ (Matczak, 2001). The results demonstrated that trait EI correlated positively with social competences in intimate situations $(r=.37$, $p<.001)$, in situations of social exposure $(r=.55$, $p<.001)$, and in situations requiring self-assertion $(r=.77, p<.001)$. These results are consistent with the notion that trait EI is associated with social competences. However, the assessment of social competences via self-descriptive measures is somewhat problematic because research subjects can provide socially desirable responses rather than truthful ones (Brackett, Rivers, Shiffman, Lerner, \& Salovey, 2006), or respondents may not actually know how good their social skills are (e.g., due to errors in self-observation and recall bias) (Paulhus, Lysy, \& Yik, 1998).

Therefore, in the present study, in an effort to overcome the shortcomings associated with the use of self-report methods and to replicate the results obtained by Szczygieł and colleagues (2015), we decided to apply a sociometric technique to evaluate social competences.

Sociometric techniques have already been used in research concerning the trait EI - social competence relationship. For example, Petrides, Sangareau, Furnham, and Frederickson (2006) demonstrated that children with high trait EI scores received more nominations from peers and teachers for positive social attributes, such as cooperation and leadership, and fewer nominations for negative social characteristics, such as aggression and delinquency (for similar results see Mavroveli \& Sánchez-Ruiz, 2011; Santesso, Dana, Schmidt, \& Segalowitz, 2006). However, the above-mentioned studies concern mainly children. The role of trait EI in predicting peer-rated social competence remains relatively under-explored in older age groups. The present study aims to contribute to the literature by presenting data from a sample of adolescents.

We considered two sociometric techniques for the study: the traditional peer nomination method, in which participants assess individuals' sociometric status, and the roster and rating method, in which each participant rates all members of a given group on an interval scale. According to Schofield and Whitley (1983), the peer nomination method should be used to assess people who know each other very well, while the roster and rating method is more appropriate for the assessment of more general inter-group acceptance. Given that we planned to conduct our study among schoolmates, who interact on 
a regular basis and are exposed to a stable peer group, we decided to use the peer nomination method.

\section{OBJECTIVES OF RESEARCH}

The purpose of the present article is twofold: to extend the findings concerning the relationship between trait EI and social competencies specified by Matczak (2001), and to assess whether trait EI predicts peer-rated social competences beyond personality traits of research subjects.

We hypothesized that trait EI is positively related to peer-rated social competencies and expected that this relationship would exist beyond personality traits, as personality traits may create a spurious correlation between these two variables. The rationale for controlling personality traits is grounded in the bulk of research which shows that personality traits are linked to trait EI (e.g., Davies, Stankov, \& Roberts, 1998; Mikolajczak, Luminet, Leroy, \& Roy, 2007; Pérez, Petrides, \& Furnham, 2005; Petrides \& Furnham, 2001; Wytykowska \& Petrides, 2007), to social behaviours predicting effectiveness in situations of social exposure and requiring self-assertion (e.g., Smółka \& Szulawski, 2011), and to peer-rated assessment (e.g., Anderson, John, Keltner, \& Kring, 2001; Scholte, van Aken, \& van Lieshout, 1997; van der Linden, Scholte, Cillessen, te Nijenhuis, \& Segers, 2010).

The relationship between trait EI and personality concerns primarily the emotional aspects of personality of extraversion and neuroticism (Szczygieł et al., 2015; Wytykowska \& Petrides, 2007). Correlations between trait EI and openness, agreeableness, and conscientiousness are also significant (and positive), but rather modest in size (Mikolajczak et al., 2007; Szczygieł et al., 2015; Wytykowska \& Petrides, 2007). Furthermore, personality traits have also been linked to peer assessment. There is evidence that highly likeable individuals have higher scores on extraversion and lower scores on neuroticism (Mervielde \& de Fruyt, 2000; van der Linden et al., 2010). Anderson et al. (2001) reported that the associations between extraversion and social status based on peer nominations ranged from .36 to .48 .

Overall, then, there is strong evidence that personality traits may influence both variables which are under study here, that is, trait EI and peer assessment of social competence. Thus, we make sure to control for personality to ensure that the relationship between trait EI and peer-rated social competencies is not driven by personality traits of research subjects, and predict the following: Trait EI predicts peer-rated social competence beyond personality traits. This hypothesis applies to three types of social competence measured in this study: in intimate situations, in situations of social exposure and in situations requiring self-assertion.

\section{PARTICIPANTS AND PROCEDURE}

\section{PARTICIPANTS AND DATA COLLECTION PROCEDURES}

The sample comprised 111 adolescents (46.95\% girls), who were aged 18 to 19 years old $(M=18.84$ years, $S D=0.37)$. The study was conducted among five classes from three public high schools in the north-western part of Poland (Pomerania District).

\section{MEASURES}

Personality traits were assessed using Costa and McCrae's (1992) Personality Inventory NEO-FFI (Polish adaptation by Zawadzki, Strelau, Szczepaniak, \& Śliwińska, 1998). NEO-FFI comprises 60 items, 12 for each of the five dimensions of adult personality: neuroticism, extraversion, openness to experience, agreeableness and conscientiousness. Items are rated on a five-point Likert scale, ranging from absolutely false to absolutely true. The results in personality dimensions are calculated by summing up the item scores.

Trait EI was measured using the TEIQue-SF (Petrides \& Furnham, 2006; Polish adaptation by Szczygiel et al., 2015). The TEIQue-SF is derived from the full form of the TEIQue (see Petrides, 2011, for a comprehensive description of the factors and subscales) and comprises 30 items rated on a seven-point scale, ranging from one (completely disagree) to seven (completely agree). A trait EI score is calculated by summing up the items' scores and dividing the result by the total number of items.

Social competences were assessed using the peer nomination method. The descriptions of three different persons were presented to the participants of the study. Each description concerned one of the social competences pointed out by Matczak (2001): intimate, social exposure and self-assertion. The description of the person having competences that determine effective functioning in intimate situations was as follows: "This person is successful in close contacts with other people. He/she is able to listen to mates' confessions. $\mathrm{He} / \mathrm{she}$ is able to share his/her own experiences. This person can be said to be able to understand other people and be helpful when there is any trouble, always trying to comprehend." The description of the person who possesses competences that determine effective functioning in situations requiring social exposure was as follows: "This person likes to be the centre of attention; being judged by other people, as well as taking part in public events, is not a problem for this person." The description of the person with competences that determine effective functioning in situations requiring self-assertion was as follows: "This person deals well 
with situations where assertiveness is required; he/ she is capable of expressing his/her view openly and clearly, but with respect to other people's opinions. For this person to demand respect for their rights does not entail costs for other people."

Each description ended with the following question: "Who in your class corresponds with the description best?" The participants were asked to nominate three classmates who suited the description best (the order of the nominees did not matter). Subsequently, we calculated how often each person was nominated by their classmates. The number of such sociometric choices was then related to the population of the entire tested class group. The total number for each nominee was then divided by the maximum total possible nominations (the whole group tested minus one) and multiplied by 100 to receive the percentage index. This means, for example, that, if student $\mathrm{X}$ gained six nominations and the total number of students in the class was 25 (including the person in question), then student X's result is $25 \%$. This formula of calculating results was important in this research, as it was conducted with five different class groups of different populations (ranging from 17 to 30 ). The result to be gained by an individual student ranged from 0 to 100 . The higher the result (the percentage of nominations), the higher the level of social competence of an individual student. The results were separately calculated for each competence (i.e., intimate competence, social exposure competence and assertive competence). The global index of a student's social competence was also calculated, by taking the mean value from the numbers concerning each competence.

\section{PROCEDURE}

Trained research assistants administered all of the measures in each of the five classrooms during regular class hours. Students participated on a voluntary basis; no one refused to participate. Participant consent was obtained prior to the data collection. Participants first completed the NEO-FFI and the TEIQueSF. Subsequently, the descriptions of three different persons were presented to the participants of the study. Each description concerned one of the social abilities: intimate competence, social exposure competence and assertive competence. The participants were then asked to nominate three classmates who suited each description best.

Participants were informed about the objectives and the procedure of the study. Information about the procedures and the instructions were read aloud. The students were informed that the research consisted of two parts. The purpose of the first part was to determine the personal features of the tested persons, while the second part aimed to determine which branches of study were preferred by the young people and which personal qualities facilitated close friendships (the answers to those questions were not analysed). The students were also informed that, in the second part, they would be presented with descriptions of three different persons, after which their task would be to give names and surnames of their classmates who best suited the description. The first part of the procedure required the participants to provide their names and surnames, while the second part was anonymous. The participants were assured that the collected data would be kept confidential and only used for research purposes. Participants' questions were answered before, during or after administration. If the teachers remained in the classroom, they were asked not to interfere with the procedure.

\section{RESULTS}

\section{PRELIMINARY ANALYSIS}

Descriptive statistics were computed for all study variables. All three indicators of social competence (i.e., intimate, social exposure, and assertive competence) loaded on one factor with an eigenvalue of 2.003 , accounting for $66.77 \%$ of the variance. All factor loadings exceeded .78. Hence, the global score of a student's social competence was calculated, as the mean value of the scores concerning each competence. Before treating all participants as one sample, $t$-tests were performed on all variables using gender as the independent variable. Only two significant differences emerged. First, the results showed that female participants reported a higher score on neuroticism than male participants $(t(109)=3.40, p=.001$, $M=22.37(S D=7.38)$ and $M=17.53(S D=7.54)$, respectively). Second, males demonstrated a higher level of extraversion than females $(t(109)=2.20$, $p=.03, M=31.17(S D=6.59)$ and $M=29.33$ $(S D=6.95)$, respectively). There were no gender differences in either trait EI scores or nominations for social competence (which are considered key variables in our study); thus, it was decided to treat the group as one sample.

Table 1 contains the means, standard deviations, internal consistency coefficients (Cronbach's $\alpha$ ) and intercorrelations of all the variables measured. The pattern of correlations between the variables was in line with our expectations. As predicted, trait EI was positively related to peer-rated intimate competence, social exposure competence, assertive competence, as well as to a global score for social competence, with $r s$ exceeding .30. Trait EI was negatively correlated with neuroticism, while positively correlated with extraversion, openness, agreeableness and conscientiousness. As expected, relationships between social competences and personality traits were espe- 
Table 1

Internal consistency reliability (Cronbach's $\alpha$ ), means, standard deviations and intercorrelations among all study variables

\begin{tabular}{|c|c|c|c|c|c|c|c|c|c|c|}
\hline & 1 & 2 & 3 & 4 & 5 & 6 & 7 & 8 & 9 & 10 \\
\hline 1. TEIQue-SF & $(.89)$ & & & & & & & & & \\
\hline 2. $\mathrm{N}$ & $-.50 * * *$ & $(.83)$ & & & & & & & & \\
\hline 3. $\mathrm{E}$ & $.46^{* * *}$ & $-.36^{* * *}$ & $(.81)$ & & & & & & & \\
\hline 4. $\mathrm{O}$ & $.27^{* *}$ & $-.25^{* *}$ & .17 & $(.71)$ & & & & & & \\
\hline 5. A & $.26^{* *}$ & $-.31^{* *}$ & .14 & .14 & $(.74)$ & & & & & \\
\hline 6. $\mathrm{C}$ & $.42^{* * *}$ & $-.27^{* *}$ & $.23^{*}$ & $.21^{*}$ & $.34^{* * *}$ & $(.83)$ & & & & \\
\hline 7. IC & $.37^{* * *}$ & $-.27^{* *}$ & $.33^{* * *}$ & .18 & $.30 * *$ & .16 & - & & & \\
\hline 8. SEC & $.39^{* * *}$ & $-.27^{* *}$ & $.37^{* * *}$ & $.26^{* *}$ & -.05 & $.21^{*}$ & $.45^{* * *}$ & - & & \\
\hline 9. $\mathrm{AC}$ & $.31^{* *}$ & $-.28^{* *}$ & $.24^{*}$ & .08 & -.07 & .06 & $.57^{* * *}$ & $.48^{* * *}$ & - & \\
\hline 10. SocComp & $.44^{* * *}$ & $-.34^{* * *}$ & $.38^{* * *}$ & $.21^{*}$ & .06 & .17 & $.80^{* * *}$ & $.80^{* * *}$ & $.85^{* * *}$ & $(.75)$ \\
\hline$M$ & 4.89 & 19.76 & 30.86 & 27.23 & 28.45 & 32.49 & 8.42 & 9.36 & 9.67 & 9.15 \\
\hline$S D$ & 0.82 & 7.82 & 6.88 & 4.95 & 5.99 & 6.80 & 7.36 & 8.49 & 8.74 & 6.70 \\
\hline
\end{tabular}

Note. TEIQue-SF - Trait Emotional Intelligence Questionnaire-Short Form, N - Neuroticism, E - Extraversion, O - Openness to Experience, A - Agreeableness, C - Conscientiousness, IC - nominations for effective functioning in intimate situations (\%), SEC - nominations for effective functioning in situations requiring social exposure (\%), AC - nominations for effective functioning in situations requiring assertiveness (\%), SocComp - a global score for social competence (\%). Diagonal values are the internal consistency estimates for each scale. ${ }^{*} p<.05,{ }^{* *} p<.01,{ }^{* *} p<.001$ (all two-tailed significance tests).

cially pronounced in relation to affectively saturated personality dimensions (i.e., extraversion and neuroticism). Extraversion was found to be positively, while neuroticism was found to be negatively, related to peer-rated social competence.

\section{PERSONALITY AND EMOTIONAL INTELLIGENCE AS PREDICTORS OF PEER-RATED SOCIAL COMPETENCE}

Correlational analyses (see Table 1) demonstrated that high trait EI scores were related to nominations for intimate competence, social exposure competence and self-assertion, as well as to a global score for social competence. These results are in accordance with our expectations. However, our main hypothesis was that trait EI is related to peer-rated social competence above and beyond personality traits. To test this hypothesis, we performed a series of hierarchical multiple regression analyses. We regressed personality traits and trait EI on each competence separately. Analyses involved two-step hierarchical regressions, entering the Big Five personality dimensions at step 1 and adding trait EI at step 2.

Peer-rated intimate competence. The results showed that personality traits which were entered in the first step of the regression equation, explained $15 \%$ of the variance. However, only extraversion and agreeableness were significantly associated with nominations for intimate competence $(\beta=.25, p=.009$ and $\beta=.23$, $p=.019$, respectively). Apart from these variables, trait EI was significant as a predictor of nominations for intimate competence $(\beta=.23, p=.04)$, explaining an additional $3 \%$ of the unique variance.

Peer-rated social exposure competence. Although personality traits explained $19 \%$ of the variance, only extraversion and agreeableness were significantly related to nominations for social exposure $(\beta=.28$, $p=.003$ and $\beta=-.21, p=.028$, respectively). Apart from these variables, trait EI was significant as a predictor of peer-rated social exposure competence $(\beta=.22$, $p=.047$ ), explaining an additional $3 \%$ of the unique variance.

Peer-rated self-assertion. The results demonstrated that personality traits explained $9 \%$ of the variance, but only neuroticism was significantly (negatively) associated with nominations for assertive competence $(\beta=-.27, p=.011)$. Apart from these variables, trait EI was significant as a predictor of nominations for assertive competence $(\beta=.24, p=.04)$, explaining an additional $2 \%$ of the unique variance.

We also examined personality traits and trait EI as predictors of a global score for social competence. The results showed that personality traits which were entered in the first step of the regression equation explained $17 \%$ of the variance. Among personality traits only neuroticism and extraversion were significantly associated with global social competence ( $\beta=-.22, p=.03$ and $\beta=.28, p=.004$, respectively). 
Trait EI was significant as a predictor of nominations for social competence $(\beta=.29, p=.01)$, explaining an additional $4 \%$ of the unique variance.

Table 2 summarizes the results of regression analyses (given that $\beta$ coefficients for the first step of the regression equation have already been reported above; coefficients reported in Table 2 refer to the final step of the equation). Taken together, these results are in line with our expectations and provide support to our hypothesis that trait EI predicts peer-rated social competence above and beyond personality traits.

\section{DISCUSSION}

The present study provides novel evidence for the association between trait EI and social competence. The results demonstrated that individuals high in trait EI received more nominations from their peers regarding intimate competence, social exposure competence and assertive competence. It means that individuals high in trait EI are perceived as being able to share their emotions with others, as well as being able to do well when at the centre of other people's attention. Moreover, individuals high in trait EI are perceived as being able to express their views openly and clearly, but with respect to other people's opinions. Similar results were reported by Mavroveli et al. (2007), who observed that individuals high in trait EI received more nominations for cooperation and leadership. However, our findings extended the results of Mavroveli et al. (2007) by demonstrating that higher trait
EI scores were related to more nominations for social competence above and beyond personality traits.

The results demonstrate that individuals high in extraversion received more nominations for intimate and social exposure competencies. These results are quite understandable, given that extraversion is related to activity, sociability, expressiveness, and a general tendency to experience positive emotions (McCrae \& John, 1992). In contrast, individuals high in neuroticism, thus experiencing a broad range of negative emotions, including irritability and nervous tension (McCrae \& John, 1992), are perceived as assertive. These results can be understood when we take into account research which shows that people who express anger and dissatisfaction in social situations are perceived as those who have power over the situation and the ability to cope with it (Fischer \& Manstead, 2008). Interestingly, agreeableness is positively related to intimate competence and negatively linked to social exposure competence. Thus, a person who is nice, sympathetic and warm is perceived as trustworthy, but also ineffective in situations of social exposure.

Although personality traits explained a substantial portion of the variance in each social competence, trait EI explained an additional amount of the unique variance in social competencies. Personality traits were included as control variables because, as discussed previously, there is substantial evidence that personality impacts both trait EI scores and social competence. By statistically controlling for this source of common variance between our predictor (trait EI) and criterion variables (nominations for so-

Table 2

Summary of hierarchical regression analysis for personality and trait El predicting peer-rated social competences

\begin{tabular}{lcccc}
\hline & $\begin{array}{c}\text { Intimate } \\
\text { competence }\end{array}$ & $\begin{array}{c}\text { Social exposure } \\
\text { competence }\end{array}$ & $\begin{array}{c}\text { Assertive } \\
\text { competence }\end{array}$ & $\begin{array}{c}\text { Global social } \\
\text { competence }\end{array}$ \\
\hline Step 1 & -.02 & -.09 & $-.20^{*}$ & -.13 \\
Neuroticism & .19 & $.22^{* *}$ & .10 & $.20^{*}$ \\
Extraversion & .07 & .15 & -.02 & .09 \\
Openness to experience & $.22^{*}$ & $-.22^{*}$ & -.19 & -.09 \\
Agreeableness & -.08 & .08 & -.05 & -.02 \\
Conscientiousness & .15 & .19 & .09 & .17 \\
$\Delta R^{2}$ adj. & $4.90^{* * *}$ & $6.25^{* * *}$ & $3.07^{*}$ & $5.49^{* * *}$ \\
$F$ & & & & $.29^{*}$ \\
Step 2 & $.23^{*}$ & $.22^{*}$ & $.24^{*}$ & .04 \\
Trait El & .03 & .03 & .02 & $5.94^{* * *}$ \\
$\Delta R^{2}$ adj. & $4.93^{* * *}$ & $6.04^{* * *}$ & $3.36^{* *}$ & \\
$F$ &
\end{tabular}

Note. All standarized $\beta$ coefficients are reported for the final step. ${ }^{*} p<.05,{ }^{* *} p<.01,{ }^{* * *} p<.001$. 
cial competence), we are able to make a more confident assertion about trait EI's contribution to successful social functioning. We need to acknowledge, however, that the contribution of trait EI in explaining peer-rated social competence was rather small.

Interestingly, the relationships between individual Big Five traits and social competence changed when all five were tested simultaneously in regression analyses. For example, in a regression with peer-rated intimate competence as a dependent variable, the beta weights of neuroticism, openness and conscientiousness were no longer significant, which was in contrast to the correlational findings. The fact that the role of individual personality traits changed when tested simultaneously suggests that these traits have overlapping variance, which could indicate the presence of higher-order factors (this issue has been analysed by van der Linden et al., 2010). Similarly, when trait EI was included in the regression analyses, the role of the individual personality traits decreased.

These results very likely reflect the problem of overlapping between personality and trait EI. Some researchers suggest that scores obtainable from the measures of trait EI are redundant with respect to existing personality measures located in Eysenckian and Big Five taxonomies (Matthews, Roberts, \& Zeidner, 2004; Matthews, Zeidner, \& Roberts, 2002). It is also possible that correlations between trait EI and personality traits reflect similarity in the items that measure the two constructs. This issue has been clarified by Petrides et al. (2007), who conducted extensive research into the validity of the trait EI construct and concluded that trait EI encompasses two sources of variance: one portion of variance that is already covered by well-established personality taxonomies, and another portion of variance that lies outside these dimensions. Petrides et al. (2007) demonstrated that the trait EI construct lies at the lower levels of personality hierarchies, due to its distinctiveness in relation to the higher-order factors described by both the Eysenck personality scales and the five-factor model scales.

Another approach to the problem of overlapping between trait EI and personality traits is to investigate the incremental validity of trait EI over and above personality in the prediction of important features of human functioning (Szczygiel, 2008). A considerable number of studies have already demonstrated incremental validity of trait EI over and above personality dimensions. Trait EI has been shown to have incremental validity in the prediction of stress (Kluemper, 2008), life satisfaction and somatic complaints (Freudenthaler, Neubauer, Gabler, Scherl, \& Rindermann, 2008) and competence to support others (Van Der Zee \& Wabeke, 2004). Our study adds to the growing literature on incremental validity of trait EI by showing that trait EI predicts social competence over personality traits.

It should be noted that the results of our study showed no gender difference in trait EI scores, and this result seems to be contrary to the findings indicating that women tend to be more emotionally expressive and have greater emotional knowledge than men (Ciarrochi, Hynes, \& Crittenden, 2005; FilaJankowska \& Szczygieł, 2004; Szczygieł, 2007). We need to remember, however, that trait EI is a multifaceted construct that covers fifteen emotion-related behavioural dispositions. Thus, one may expect that there are areas in which women are superior to men and areas in which men are superior to women. This is what the research shows when the full version of the TEIQue is used. For example, Mikolajczak and colleagues (2007) in their study conducted in a French sample observed that women scored higher on Emotionality while men scored higher on Self-Control and Sociability. Similar gender differences were observed in a Polish study (Wytykowska \& Petrides, 2007), with women scoring higher on Emotionality and men scoring higher on Self-Control. The TEIQue-SF, which was used in our study, refers only to global trait EI, and this probably explains why we did not observe gender difference in trait EI scores.

\section{LIMITATIONS AND FUTURE DIRECTIONS}

There are limitations to the present study which should be acknowledged. Firstly, physical attractiveness of the participants was not taken into consideration. The results of numerous studies show that individuals are judged according to their level of physical attractiveness. Specifically, attractive people are perceived as more assertive, talented, honest and intelligent than less attractive people (e.g., Dion, Berscheid, \& Walster, 1972; Eagly, Ashmore, Makhijani, \& Longo; 1991; Feingold, 1992). Secondly, we did not control for the popularity of participants. There is a possibility of overlap between sociometric popularity and peer-rated social competencies (Cillessen $\&$ Rose, 2005). Therefore, future studies should take into account both the physical attractiveness and popularity of the participants. Thirdly, the generalizability of this study is limited to a group of adolescents. We focused on adolescence because this period in life is crucial for social development and relationships with peers, social status and peer popularity, all of which work as mechanisms of social adjustment (La Greca \& Harrison, 2005; Mavroveli et al., 2007; Szczygieł \& Kiełkiewicz, 2005). Future studies are needed to examine whether similar results emerge among adults.

\section{CONCLUSIONS}

Our research complements existing evidence confirming that trait EI (or trait emotional self-efficacy) 
contributes to successful social functioning. It also extends previous research which demonstrated that trait EI was positively related to self-reported social competences (Szczygieł et al., 2015). In the current study we were able to rule out the disadvantages associated with self-reported social competence, such as self-deception (a positively biased response that respondents actually believe to be true) and impression management (an intention to create a favourable impression and deceive others) (Paulhus, 1984). Of particular importance, this relationship remained statistically significant even after controlling for Big Five variance. It also needs to be emphasized that our research demonstrates that trait EI translates into observable behaviour, which means that individuals high in trait EI possess and display skills which are noticed and identified by other people.

\section{RefERENCES}

Anderson, C., John, O. P., Keltner, D., \& Kring, A. M. (2001). Who attains social status? Effects of personality and physical attractiveness in social groups. Journal of Personality and Social Psychology, 81, 116.

Austin, E. J., \& Saklofske, D. H. (2010). Introduction to the special issue. Australian Journal of Psychology, 62, 1-4.

Brackett, M. A., Rivers, S., Shiffman, S., Lerner, N., \& Salovey, P. (2006). Relating emotional abilities to social functioning: A comparison of performance and self-report measures of emotional intelligence. Journal of Personality and Social Psychology, 91, 780-795.

Chamorro-Premuzic, T., Bennett, E., \& Furnham, A. (2007). The happy personality: Mediational role of trait emotional intelligence. Personality and Individual Differences, 42, 1633-1639.

Ciarrochi, J., Deane, F. P., Wilson, C. J., \& Rickwood, D. (2002). Adolescents who need help the most are the least likely to seek it: The relationship between low emotional competence and low intention to seek help. British Journal of Guidance and Counselling, 30, 173-188.

Ciarrochi, J., Chan, A., \& Caputi, P. (2000). A critical evaluation of the emotional intelligence construct. Personality and Individual Differences, 28, 539-561.

Ciarrochi, J., Hynes, K., \& Crittenden, N. (2005). Can men do better if they try harder: Sex and motivational effects on emotional awareness. Cognition \& Emotion, 19, 133-141.

Cillessen, A. H., \& Rose, A. J. (2005). Understanding popularity in the peer system. Current Directions in Psychological Science, 14, 102-105.

Costa, P. T. Jr., \& McCrae, R. R. (1992). Revised NEO Personality Inventory (NEO-PI-R) and NEO Five-Factor Inventory (NEO-FFI). Professional man- ual. Odessa, FL: Psychological Assessment Resources.

Davies, M., Stankov, L., \& Roberts, R. D. (1998). Emotional intelligence: In search of an elusive construct. Journal of Personality and Social Psychology, 75, 989-1015.

Dion, K., Berscheid, E., \& Walster, E. (1972). What is beautiful is good. Journal of Personality and Social Psychology, 24, 285-290.

Eagly, A. H., Ashmore, R. D., Makhijani, M. G., \& Longo, L. C. (1991). What is beautiful is good, but...: A meta-analytic review of research on the physical attractiveness stereotype. Psychological Bulletin, 110, 109-128.

Feingold, A. (1992). Good-looking people are not what we think. Psychological Bulletin, 111, 304-341.

Fila-Jankowska, A., \& Szczygieł, D. (2004). Wpływ pomiaru pobudzenia fizjologicznego na deklarowaną intensywność emocji - różnice między płciami [The impact of monitoring parameters of emotional arousal on declared intensity of emotions - sex differences]. Psychologia Jakości Życia, 3, 165-182.

Fischer, A. H., \& Manstead, A. S. R. (2008). Social functions of emotion. In M. Lewis, J. Haviland-Jones, \& L. Feldman Barrett (eds.), Handbook of emotions ( $3^{\text {rd }}$ ed.) (pp. 456-468). New York: Guilford.

Fredrickson, B. (2001). The role of positive emotions in positive psychology: The broaden-and-build theory of positive emotions. American Psychologist, 56, 218-226.

Freudenthaler, H. H., Neubauer, A. C., Gabler, P., Scherl, W. G., \& Rindermann, H. (2008). Testing and validating the trait emotional intelligence questionnarire (TEIQue) in a German-speaking sample. Personality and Individual Differences, 45, 673-678.

Jasielska, A., \& Leopold, M. A. (2000). Kompetencja a inteligencja emocjonalna - pojęcia tożsame czy różne? [Emotional competence versus emotional intelligence - the same or different concepts?]. Forum Oświatowe, 23, 5-32.

Keltner, D., \& Haidt, J. (2001). Social functions of emotions. In T. J. Mayne \& G. A. Bonanno (eds.), Emotions: Current issues and future directions. Emotions and social behavior (pp. 192-213). New York: Guilford.

Kluemper, D. H. (2008). Trait emotional intelligence: The impact of core-self evaluations and social desirability. Personality and Individual Differences, 44, 1402-1412.

La Greca, A. M., \& Harrison, H. M. (2005). Adolescent peer relations, friendships, and romantic relationships: Do they predict social anxiety and depression? Journal of Clinical Child and Adolescent Psychology, 34, 49-61.

Levenson, R. W. (1999). The intrapersonal functions of emotion. Cognition and Emotion, 13, 481-504. 
Lopes, P. N., Brackett, M. A., Nezlek, J. B., Schütz, A., Sellin, I., \& Salovey, P. (2004). Emotional intelligence and social interaction. Personality and Social Psychology Bulletin, 30, 1018-1034.

Lopes, P. N., Salovey, P., \& Straus, R. (2003). Emotional intelligence, personality, and the perceived quality of social relationships. Personality and Individual Differences, 35, 641-658.

Lopes, P. N., Salovey, P., Côté, S., Beers, M., \& Petty, R. E. (2005). Emotion regulation abilities and the quality of social interaction. Emotion, 5, 113-118.

Lumley, M. A., Gustavson, B. J., Partridge, R. T., \& Labouvie-Vief, G. (2005). Assessing alexithymia and related emotional ability constructs using multiple methods: Interrelationships among measures. Emotion, 5, 329-342.

Martowska, K. (2012). Psychologiczne uwarunkowania kompetencji spotecznych [Psychological determinants of social competencies]. Warszawa: LiberiLibri.

Martowska, K. (2014). Temperamental determinants of social competencies. Polish Psychological Bulletin, 45, 128-133.

Matczak, A. (2001). Kwestionariusz Kompetencji Spotecznych [The Social Competence Questionnaire]. Warszawa: Pracownia Testów Psychologicznych Polskiego Towarzystwa Psychologicznego.

Matczak, A. (2007). Rola inteligencji emocjonalnej [The role of emotional intelligence]. Studia Psychologiczne, 45, 9-18.

Matczak, A., \& Knopp, K. A. (2013). Znaczenie inteligencji emocjonalnej $w$ życiu człowieka [The importance of emotional intelligence in human functioning]. Warszawa: LiberiLibri.

Matczak, A., \& Martowska, K. (2011). Z badań nad uwarunkowaniami kompetencji emocjonalnych [From research on determinants of emotional competence]. Studia Psychologica, 11, 5-18.

Matthews, G., Roberts, R. D., \& Zeidner, M. (2004). Seven myths about emotional intelligence. Psychological Inquiry, 15, 179-196.

Matthews, G., Zeidner, M., \& Roberts, R. D. (2002). Emotional intelligence: Science and myth. Cambridge, MA: MIT Press.

Mavroveli, S., \& Sánchez-Ruiz, M. J. (2011). Trait emotional intelligence influences on academic achievement and school behaviour. British Journal of Educational Psychology, 81, 112-134.

Mavroveli, S., Petrides, K. V., Rieffe, C., \& Bakker, F. (2007). Trait emotional intelligence, psychological well-being and peer-rated social competence in adolescence. British Journal of Developmental Psychology, 25, 263-275.

Mayer, J. D., \& Salovey, P. (1997). What is emotional intelligence? In P. Salovey \& D. Sluyter (eds.), Emotional development and emotional intelligence: Educational implications (pp. 3-31). New York: Basic Books.
Mayer, J. D., Salovey, P., \& Caruso, D. R. (2004). Emotional Intelligence: Theory, Findings, and Implications. Psychological Inquiry, 15, 197-215.

Mayer, J. D., Salovey, P., Caruso, D. R., \& Sitarenios, G. (2003). Measuring emotional intelligence with the MSCEIT V 2.0. Emotion, 3, 97-105.

McCrae, R. R., \& John, O. P. (1992). An introduction to the five-factor model and its applications. Journal of Personality, 60, 175-215.

McCrae, R. R. (2000). Emotional intelligence from the perspective of the five-factor model of personality. In R. Bar-On \& J. D. A. Parker (eds.), The handbook of emotional intelligence (pp. 261-276). San Francisco: Jossey-Bass.

McElravy, L. J., \& Hastings, L. J. (2014). Profiling the youth leader: Personality and emotional intelligence trends and their relationship to leadership skills. Journal of Agricultural Education, 55, 134-151.

Mervielde, I., \& De Fruyt, F. (2000). The Big Five personality factors as a model for the structure of children's peer nominations. European Journal of Personality, 14, 91-106.

Mikolajczak, M., Luminet, O., Leroy, C., \& Roy, E. (2007). Psychometric properties of the trait emotional intelligence questionnaire: Factor structure, reliability, construct, and incremental validity in a French speaking population. Journal of Personality Assessment, 88, 338-353.

Ogińska-Bulik, N. (2005). Emotional intelligence in the workplace: exploring its effects on occupational stress and health outcomes in human service workers. International Journal Occupational Medicine and Environmental Health, 18, 167-175.

Paulhus, D. L. (1984). Two-component models of socially desirable responding. Journal of Personality and Social Psychology, 46, 598-609.

Paulhus, D. L., Lysy, D. C., \& Yik, M. S. (1998). Self-report measures of intelligence: Are they useful as proxy IQ tests? Journal of Personality, 66, 525-554.

Pérez, J. C., Petrides, K. V., \& Furnham, A. (2005). Measuring trait emotional intelligence. In R. Schulze \& R. D. Roberts (eds.), International Handbook of Emotional Intelligence (pp. 181-201). Cambridge, MA: Hogrefe \& Huber.

Petrides, K. V. (2011). Ability and trait emotional intelligence. In T. Chamorro-Premuzic, A. Furnham, \& S. von Stumm (eds.), The Wiley-Blackwell Handbook of Individual Differences (pp. 656-678). New York: Wiley.

Petrides, K. V., \& Furnham, A. (2001). Trait emotional intelligence: Psychometric investigation with reference to established trait taxonomies. European Journal of Personality, 15, 425-448.

Petrides, K. V., \& Furnham, A. (2003). Trait emotional intelligence: Behavioural validation in two studies of emotion recognition and reactivity to mood induction. European Journal of Personality, 17, 39-57. 
Petrides, K. V., \& Furnham, A. (2006). The role of trait emotional intelligence in a gender-specific model of organizational variables. Journal of Applied Social Psychology, 36, 552-569.

Petrides, K. V., Pita, R., \& Kokkinaki, F. (2007). The location of trait emotional intelligence in personality factor space. British Journal of Psychology, 98, 273-289.

Petrides, K. V., Sangareau, Y., Furnham, A., \& Frederickson, N. (2006). Trait emotional intelligence and children's peer relations at school. Social Development, 15, 537-547.

Salovey, P., \& Mayer, J. D. (1990). Emotional intelligence. Imagination, Cognition, and Personality, 9, 185-211.

Salovey, P., Bedell, B., Detweiler, J. B., \& Mayer, J. (1999). Coping intelligently: emotional intelligence and the coping process. In C. R. Snyder (ed.), Coping: the psychology of what works (pp. 141-164). New York: Oxford University Press.

Santesso, L. D., Dana, L. R., Schmidt, L. A., \& Segalowitz, S. J. (2006). Frontal electroencephalogram activation asymmetry, emotional intelligence, and externalizing behaviors in 10-year-old children. Child Psychiatry and Human Development, 36, 311-328.

Schofield, J. W., \& Whitley, B. E. Jr. (1983). Peer nomination vs. rating scale measurement of children's peer preferences. Social Psychology Quarterly, 46, 242-251.

Scholte, R. H., van Aken, M. A., \& van Lieshout, C. F. (1997). Adolescent personality factors in self-ratings and peer nominations and their prediction of peer acceptance and peer rejection. Journal of Personality Assessment, 69, 534-554.

Sevdalis, N., Petrides, K. V., \& Harvey, N. (2007). Trait emotional intelligence and decision - related emotions. Personality and Individual Differences, 42, 1347-1358.

Smółka, P., \& Szulawski, M. (2011). Personality traits and motivational traits as predictors of social competence. Implication for occupational selection process. Education of Economists and Managers, 22, 111-126.

Szczygieł, D. (2007). Zdolniejsze kobiety czy mniej zmotywowani mężczyźni? Różnice między płciami w zróżnicowaniu i złożoności werbalizacji emocji [Sex differences in complexity and differentiation of verbalization of emotions - ability or motivation?]. Psychologia, Edukacja i Spoteczeństwo, 4, 47-66.

Szczygieł, D. (2008). Inteligencja emocjonalna więcej niż IQ i osobowość? O potrzebie i znaczeniu sprawdzania trafności dodanej narzędzi mierzących inteligencję emocjonalną [Emotional Intelligence - more than IQ and personality? The need and the importance of testing incremental validity of emotional intelligence instruments].
In M. Śmieja \& J. Orzechowski (eds.), Inteligencja emocjonalna: fakty, mity, kontrowersje [Emotional intelligence: Facts, myths, controversies] (pp. 136-152). Warszawa: PWN.

Szczygieł, D., \& Bazińska, R. (2013). Emotional intelligence as a moderator in the relationship between negative emotions and emotional exhaustion among employees in service sector occupations. Polish Psychological Bulletin, 44, 75-86.

Szczygieł, D., \& Baka, Ł. (2016). The role of personal resources in the relationship between job stressors and emotional exhaustion. Polish Journal of Applied Psychology, 14, 135-154.

Szczygieł, D., Buczny, J., \& Bazińska, R. (2012). Emotion regulation and emotional information processing: The moderating effect of emotional awareness. Personality and Individual Differences, 52, 433-437.

Szczygieł, D., Jasielska, A., \& Wytykowska, A. (2015). Psychometric properties of the Polish version of the Trait Emotional Intelligence Questionnaire-Short Form. Polish Psychological Bulletin, 46, 447-459.

Szczygieł, D., \& Kiełkiewicz J. (2005). Inteligencja emocjonalna i powodzenie szkolne [Emotional intelligence and emotional intelligence and academic achievement]. Psychologia Rozwojowa, 10, 59-68.

van der Linden, D., Scholte, R. H., Cillessen, A. H., te Nijenhuis, J., \& Segers, E. (2010). Classroom ratings of likeability and popularity are related to the Big Five and the general factor of personality. Journal of Research in Personality, 44, 669-672.

Van Der Zee, K., \& Wabeke, R. (2004). Is trait-emotional intelligence simply or more than just a trait? European Journal of Personality, 18, 243-263.

Villanueva, J. J., \& Sanchez, J. C. (2007). Trait emotional intelligence and leadership self-efficacy: Their relationship with collective efficacy. The Spanish Journal of Psychology, 10, 349-357.

Wytykowska, A., \& Petrides, K. V. (2007). Inteligencja emocjonalna jako dyspozycja. Polska adaptacja skali do badania inteligencji emocjonalnej jako cechy [Polish adaptation of the Trait Emotional Intelligence Questionnaire (TEIQue)]. Psychologia, Edukacja i Spoleczeństwo, 4, 97-110.

Zawadzki, B., Strelau, J., Szczepaniak, P., \& Śliwińska, M. (1998). Inwentarz osobowości NEO-FFI Costy i McCrae. Podręcznik [Personality Inventory NEO-FFI by Costa and McCrae. Polish Adaptation. Handbook]. Warszawa: Pracownia Testów Psychologicznych Polskiego Towarzystwa Psychologicznego. 